\title{
A fresh look at the incidence of protein deficiency in Pakistan
}

\author{
By M. ANWAR HUSSAIN \\ Nutrition Division, National Health Laboratories, Islamabad, Pakistan
}

(Received 7 March 1972-Accepted 21 August 1972)

\begin{abstract}
I. The method of Sukhatme ( $197 \circ \mathrm{b}$ ), which takes into account the interrelationship between dietary protein and energy, has been applied to the dietary survey results collected during the nation-wide Nutrition Survey of West Pakistan. It was found that most of the protein deficiency that occurs in Pakistan is conditioned by energy deficiency. The incidence rises from $\mathrm{r} 3$ to $40 \%$ when cases conditioned by energy deficiency are taken into account. Protein deficiency as such exists in only $2 \%$ of families compared with $11 \%$ of families which are deficient in both protein and energy. 'These findings indicate the magnitude of the protein problem in Pakistan.

2. In view of these findings, it is obvious that, unless the energy need is met, increased protein production will not help much to improve the situation and may be a costly approach to the solution of the protein problem in Pakistan.
\end{abstract}

The Nutrition Surveys conducted in West Pakistan (Government of Pakistan, 1970) revealed a widespread prevalence of clinical manifestations of protein-energy malnutrition; yet they showed that, on the average, even the households with the lowest income consumed a diet containing an adequate amount of protein. The Report of the Protein Committee (National Science Council of Pakistan, 1968) emphasized the magnitude of the protein gap based on food balance sheets but dismissed the findings of the survey as unrepresentative because the survey included only rich areas of Pakistan and did not take into account the wastage factor of $10 \%$. In the survey report, the adequacy or inadequacy of the diet was judged by comparing the amount of protein consumed with the recommended allowance; the Report of the Protein Committee compared availability per head with the requirement. But in both reports the energy content of the diet was not taken into account. There is conclusive evidence in the literature that, unless the energy need of the consumer is satisfied, the protein consumed is utilized less efficiently and, as a result, protein deficiency may still arise, primarily owing to the deficiency of energy in the diet. Therefore, the traditional method of comparing intake with recommended allowance will miss the cases of protein deficiency which are conditioned by energy deficiency. It is the object of this paper to consider anew the West Pakistan Nutrition Survey findings in the light of this protein-energy interrelationship.

\section{METHODS AND RESULTS}

\section{Material}

During the nation-wide nutrition survey of West Pakistan, dietary surveys were carried out in nine rural areas and five urban areas. The survey covered 916 rural and ${ }_{5} \mathbf{6}$ urban households. The information on dietary intake was collected by trained investigators who weighed the daily food intake of each household, beginning with breakfast and ending with dinner. The income of the household was recorded. 
The rural and urban areas were selected by a multistage random sampling method. The families werc selected by a table of random numbers. No warning was given to the families before the survey began.

The recorded consumption of each food in each household was used to calculate protein and energy consumption from the international FAO food tables (Chatineld, I954). The amount of protein consumed was then converted to the reference protein value. In our calculations we used a net protein utilization (NPU) value of 0.8 for animal protein (this is the value for milk which contributes most of the animal protein in the Pakistan diet) and a NPU value of 0.5 for vegetable protein.

The nutrition unit (a nutrition unit represents the requirements of a reference man; FAO, 1957) was calculated separately for protein and energy from the recorded information of the age and sex structure for each household (see Sukhatme, 1970b), using the latest recommendations for protein and energy requirements (FAO, 1957, I965). The mean temperature in Pakistan was assumed to be $25^{\circ}$; accordingly, a correction of $-7.5 \%$ was made for the energy requirement of the reference man. The information was then tabulated in the form of bivariate distribution of energy and protein intake in households on a nutrition unit basis.

The daily requirements of the reference man weighing $65 \mathrm{~kg}$ werc assumed to be I2. $385 \mathrm{MJ}$ and $38 \mathrm{~g}$ reference protein. In the absence of any reliable information on body-weight, a weight of $65 \mathrm{~kg}$ was assumed for the reference man. This may have overestimated the incidence of deficiency to some extent but it appears reasonable because, according to FAO (1957), for the adjustment of body size in cases of emaciation resulting from prolonged undernutrition, the actual body-weight should be ignored and a target or desired body-weight should be used instead. A substantial proportion of the population of Pakistan is undernourished, so that the average body-weight of Pakistanis is lower than if they were well fed; bccause of this, if we had used the average body-weight in our calculations we would have underestimated the incidence of malnutrition and we would have overlooked many instances of a lesser degree of malnutrition.

\section{Energy and protein requirement}

The daily requirements for protein and energy for Pakistanis are given in Table 2: the values are based on the latest FAO $(1957,1965)$ recommendations on protein and energy requirements (energy values are corrected for temperature, see above). The ratio of energy supplied by utilizable protein to total metabolizable energy (NDp: $\mathrm{E}$ ) is also given. The NDp: $\mathrm{E}$ requirement ratio gradually increases with advancing age except for infants, whose NDP:E requirement equals that of an adult man of the reference type.

\section{Total energy and protein gap}

A comparative statement of average energy and protein consumptions and requirements at the physiological level on the nutrition unit basis is given in Table 3 . On average, the energy deficit is only $3.3 \%$ in Pakistan. There is a nominal energy surplus of $1.3 \%$ in rural areas compared with a deficit of $12.2 \%$ in urban areas. A part of the apparent deficit in urban areas may be due to the use of the same scale of requirement 
Vol. 29

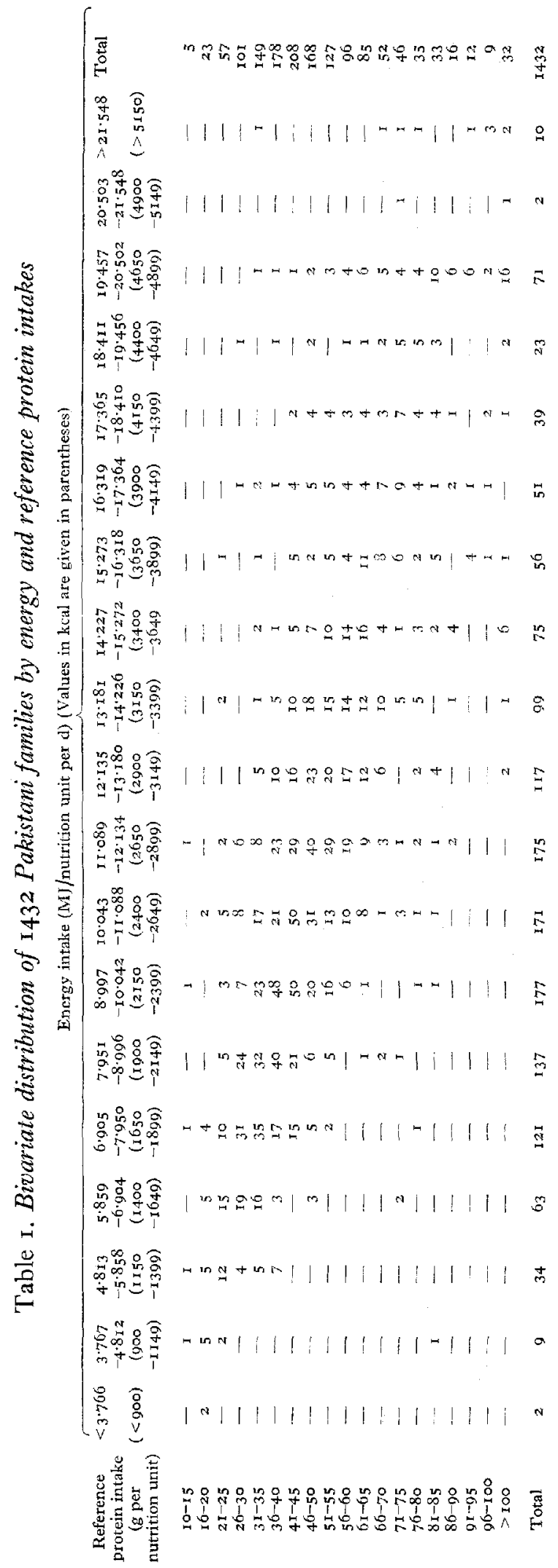


Table 2. Recommended daily requirements for energy, and protein given in terms of reference protein, and $\mathrm{NDP}: \mathrm{E}$ ratio for Pakistanis

\begin{tabular}{|c|c|c|c|c|}
\hline \multirow{2}{*}{$\begin{array}{l}\text { Age } \\
\text { (years) }\end{array}$} & \multicolumn{2}{|c|}{$\begin{array}{c}\text { Average energy } \\
\text { requirement }\end{array}$} & \multirow{2}{*}{$\begin{array}{c}\text { Average } \\
\text { protein } \\
\text { requirement } \\
\text { (g) }\end{array}$} & \multirow{2}{*}{$\begin{array}{l}\text { NDp: } E \\
\text { ratio }\end{array}$} \\
\hline & $(\mathrm{MJ})$ & (kcal) & & \\
\hline $0-1$ & 4335 & I036 & I 3 & 0.050 \\
\hline$I-3$ & 5.033 & 1203 & 12 & 0.040 \\
\hline $4-6$ & $6 \cdot 581$ & $\mathrm{r} 573$ & I 5 & 0.038 \\
\hline $7-9$ & $8 \cdot 129$ & $\begin{array}{l}073 \\
1943\end{array}$ & 21 & 0.043 \\
\hline $10-12$ & $9 \cdot 678$ & 2313 & 26 & 0.045 \\
\hline I $3-15$, boys & r 1995 & 2867 & 34 & 0.047 \\
\hline $13-15$, girls & 10.062 & 2405 & 34 & 0.056 \\
\hline 16-19, boys & +3.933 & 3330 & 40 & 0.048 \\
\hline I6-19, girls & $9 \cdot 288$ & 22,20 & 35 & 0.063 \\
\hline Adults, male & โ2.385 & 2960 & 38 & $0.05 \mathrm{~T}$ \\
\hline Adults, female & 8.903 & $2 \pi 28$ & 32 & 0.060 \\
\hline Pregnant women & 10.577 & 2528 & $\begin{array}{l}34 \\
38\end{array}$ & 0.060 \\
\hline Lactating women & 3.087 & 3128 & 47 & 0.060 \\
\hline
\end{tabular}

NDp:E, ratio of energy supplied by utilizable protein to total metabolizable energy.

Table 3. Energy and protein intakes compared with requirements in urban and nural areas of Pakistan

Mean energy intake/nutrition unit per d (MJ)

Energy requirement/nutrition unit per d (MJ)

Energy gap (\%)

Mean reference protein intake/nutrition unit per $\mathrm{d}(\mathrm{g})$

Reference protein requirement/nutrition unit per $\mathrm{d}(\mathrm{g})$

Protein gap $(\%)$

Rural
$\mathrm{I} 2 \cdot 55$
$\mathrm{r} 2 \cdot 38$
$+\mathrm{I} \cdot 3$
$50 \cdot 5$
38
$+32 \cdot 9$

Total

I I.98

1 $2 \cdot 38$

$-3 \cdot 3$

$48 \cdot 4$

38

$+27 \cdot 4$

for rural and urban districts. The urban population may be more sedentary and will therefore have a lower requirement. There is a total excess consumption of $27.4 \%$ protein $(32.9 \%$ in rural and $17.9 \%$ in urban areas).

When requirements are taken at the retail level, that is at the physiological level plus $10 \%$ for wastage, the energy deficit increases from 3.3 to $13.3 \%$ (I $13 \%$ for rural and $22.2 \%$ for urban areas). The protein consumption is still substantially $(10.4 \%)$ in excess of the requirement. This highlights the serious nature of energy deficiency in Pakistan.

\section{Energy deficiency}

Normally in a well-nourished population most of the households are likely to have an energy intake, calculated on a nutrition unit basis, that is higher than the mean minus three times the standard deviation (Sukhatme, r96r). The standard deviation. of the daily energy expenditure of a man of the reference type is about $\mathrm{I} \cdot 674 \mathrm{MJ}$ (400 kcal) (Sukhatme, 1970a); so the standard deviation for a household with an average nutrition unit of $4 \cdot 4$ is about $1 \cdot 674 \div \sqrt{ }(4 \cdot 4)$, that is $0.795 \mathrm{MJ}$. Therefore, the critical value for estimating energy deficiency could be taken as $12 \cdot 385-2 \cdot 385$ [i.e. $3 \times 0.795]=10 \mathrm{MJ}(2390 \mathrm{kcal})$. 
After reviewing the literature on energy expenditure, the FAO Committee on Calorie Requirements (FAO, 1957) concluded that the energy requirements of most people in any population are likely to be met by the provision of between 10.042 and I6.736 MJ (2400 and $4000 \mathrm{kcal}) / \mathrm{d}$, a range of $\pm 3.345 \mathrm{MJ}( \pm 800 \mathrm{kcal}) / \mathrm{d}$ around the average requirement of the FAO reference man. Therefore, we have taken the lower limit of this range as the criterion for assessing energy deficiency; incidentally, this value is almost the same as that derived above (i.e. 1o MJ).

Applying this criterion to the bivariate distribution, it is found that, on a nutritionunit basis, $38 \%(543)[48 \%(238)$ for urban and $33 \%$ (305) for rural] of the households have an inadequate energy supply.

Food is not distributed evenly according to the nutritional needs of the members of the family. It is our experience that the wage-earners get the best of all food, leaving the other members of the family to eat the left-overs. This may be particularly true in the poor-income groups, though no actual details are available of the distribution of food within the family. The same tendency is true in families which are consuming more than the critical amount. In the absence of details on the distribution of food within the family, following the assumption of Sukhatme (1970 b), it is assumed that these groups broadly counterbalanced each other and, therefore, the households consuming less than the critical limit for energy may be equated with the prevalence of energy deficiency. Considering the average income level of the families included in the survey, it is most likely that the error involved will underestimate rather than overestimate the prevalence of energy deficiency.

\section{Protein deficiency}

The average requirement of the reference man is taken as $38 \mathrm{~g}$ reference protein. According to $\mathrm{FAO}(1965)$, a level of intake $20 \%$ below the average requirement will not meet the protein need of at least $97 \%$ of the population and, therefore, in the present paper the critical limit for estimating protein deficiency was taken as $38{ }^{\circ} 0-$ $7^{\circ} 6\left[7^{\circ} 6=20 \%\right.$ of $\left.3^{8} \mathrm{~g}\right]$, that is $3^{\circ} \cdot 4 \mathrm{~g}$, or a round figure of $30 \mathrm{~g}$, below which protein deficiency was taken to exist. Using this criterion it was found that only $13 \%$ (186) ( $10.7 \%(98)$ rural and $17.1 \%(88)$ urban) households had protein deficiency.

\section{Energy and protein deficiency}

A strong correlation between energy and protein deficiency can be seen in Table 4: II \% of the households are found to be deficient in both protein and energy; the proportions of households for rural and urban areas are 8.7 and $14.9 \%$ respectively. Eighty-four per cent of the protein-deficient households are also energy-deficient.

\section{Incidence of protein deficiency conditioned by energy deficiency}

From the foregoing discussion it is evident that $13 \%$ of the households are proteindeficient, compared with $38 \%$ that are energy-deficient; that is energy deficiency is three times more frequent than protein deficiency. In this analysis it is assumed that utilization of protein in the diet is independent of energy intake. There is conclusive evidence in the literature that this assumption is wrong because where 'the calorie 
Table 4. Incidence of energy deficiency and protein deficiency in Pakistan: $2 \times 2$ classification of households according to whether or not they are deficient in energy and protein

\begin{tabular}{|c|c|c|c|c|c|c|c|c|c|}
\hline & \multicolumn{3}{|c|}{ Rural } & \multicolumn{3}{|c|}{ Urban } & \multicolumn{3}{|c|}{ Rural +urban } \\
\hline & PD & NPD & Total & PD & NPD & Total & $P D$ & NPI & Total \\
\hline ED & $\begin{array}{c}80 \\
(8 \cdot 7)\end{array}$ & $\begin{array}{c}225 \\
\left(24^{\circ} 6\right)\end{array}$ & $\begin{array}{c}305 \\
(33 \cdot 3)\end{array}$ & $\begin{array}{c}77 \\
\left(14^{\circ} 9\right)\end{array}$ & $\begin{array}{c}16 \mathrm{I} \\
\left(3 \mathrm{I}^{\prime} \cdot 2\right)\end{array}$ & $\begin{array}{c}238 \\
(46 \cdot 1)\end{array}$ & $\begin{array}{c}157 \\
(\mathrm{II} \cdot 0)\end{array}$ & $\begin{array}{c}3^{86} \\
\left(27^{\circ} 0\right)\end{array}$ & $\begin{array}{c}543 \\
\left(37^{\circ} 9\right)\end{array}$ \\
\hline NED & $\begin{array}{l}18 \\
(2 \cdot 0)\end{array}$ & $\begin{array}{c}593 \\
(64 \cdot 7)\end{array}$ & $\begin{array}{c}6.1 \\
(66 \cdot 7)\end{array}$ & $\begin{array}{c}\text { II } \\
(2 \cdot 1)\end{array}$ & $\begin{array}{c}267 \\
(51 \cdot 7)\end{array}$ & $\begin{array}{c}278 \\
\left(53^{\circ} \cdot 9\right)\end{array}$ & $\begin{array}{c}29 \\
(2 \cdot 0)\end{array}$ & $\begin{array}{c}860 \\
(60 \cdot I)\end{array}$ & $\begin{array}{c}889 \\
(62 \cdot 1)\end{array}$ \\
\hline Total & $\begin{array}{c}98 \\
(10 \cdot 7)\end{array}$ & $\begin{array}{c}818 \\
(89 \cdot 3)\end{array}$ & $\begin{array}{r}916 \\
(100)\end{array}$ & $\begin{array}{c}88 \\
(\mathrm{I} 7 \cdot \mathrm{I})\end{array}$ & $\begin{array}{c}428 \\
(82 \cdot 9)\end{array}$ & $\begin{array}{r}516 \\
(100)\end{array}$ & $\begin{array}{c}186 \\
\left(13^{\circ} 0\right)\end{array}$ & $\begin{array}{l}1246 \\
\left(87^{\circ} 0\right)\end{array}$ & $\begin{array}{l}1432 \\
\text { (100) }\end{array}$ \\
\hline
\end{tabular}

PD, protein deficient; NPD, not protein deficient; ED, energy deficient; NED, not energy deficient. Figures in parentheses are percentages.

needs are not met by the diet, the efficiency of protein utilization is reduced, i.e. below a critical level of energy intake the nutritive value of protein to the consumer diminishes (FAO, 1965$)$.

Miller \& Payne (196r) have shown that, on the average, $25^{\circ} 94 \mathrm{~kJ}(6.2 \mathrm{kcal})$ is needed to produce $4.184 \mathrm{~kJ}$ ( $\mathrm{I} \mathrm{kcal}$ ) of protein, that is for protein synthesis a reference man will need $3 \cdot 94 \mathrm{I} \mathrm{MJ}(942 \mathrm{kcal}$, i.e. $38 \times 4 \times 6 \cdot 2$; [' $\times 4$ ' since proteins contain about $4 \mathrm{kcal} / \mathrm{g}]$ over and above his basal need. The energy requirement of basal metabolism is approximately $5.89 \mathrm{r} \mathrm{MJ}(1408 \mathrm{kcal})$ : therefore, a reference man will need $5.89 \mathrm{I}+$ $3.94 \mathrm{I} \mathrm{MJ}=9.83^{2} \mathrm{MJ}\left(1408+94^{2}=235^{\circ} \mathrm{kcal}\right)$ at the physiological level; allowing for a small wastage, it may be assumed to be Io MJ, that is equal to the critical lower limit for energy requirements discussed earlier.

Following the method of Sukhatme ( $1970 b)$, Table 4 is set out on the basis of whether the diet is deficient or not deficient in energy and protein. The values were taken from the table of bivariate distribution for energy and protein, and they imply a continuous gradation. The lines of demarcation are set at the critical level for protein and energy. From this table it is evident that in assessing true prevalence of protein deficiency we must include those households that cannot utilize dietary protein for want of energy. In other words, total percentage of protein deficiency will be given by:

$\begin{array}{ccccc}\begin{array}{c}\text { protein-deficient, } \\ \text { energy-deficient }\end{array} & + & \begin{array}{c}\text { protein-deficient, } \\ \text { not energy-deficient }\end{array} & + & \begin{array}{c}\text { not protein-deficient, } \\ \text { energy-deficient, }\end{array} \\ \text { that is I I } & + & 2 & + & 27=40 \% .\end{array}$

Thus the total incidence of protein deficiency rises from $\mathrm{I} 3$ to $40 \%$ when proteinenergy interrelationship is taken into account (the rise for rural areas is from 10.7 to $33.3 \%$ and that for urban areas from $17 \cdot \mathrm{I}$ to $46 \cdot \mathrm{I} \%$ ). Therefore, we are likely to underestimate the protein deficiency by about $27 \%$ if this relationship is not taken into account. This analysis brings out clearly that about two-thirds of the protein deficiency in Pakistan is conditioned by energy deficiency. 


\section{DISCUSSION}

From Table 4 it is evident that the prevalence of protein deficiency increases threefold when households that cannot utilize protein, owing to lack of energy in their diet, are included. Further, households that are deficient in both protein and energy in their diet are faced with a situation which can be termed as 'balanced starvation'. The NDP:E ratio of their diet is more than the requirement of an adult healthy man. Thus, the protein deficiency is the result of inadequate consumption of food. Therefore, the need for this group is for an increased quantity of the type of food usually consumed. However, provision of additional protein would also be helpful and desirable.

Consumption of a diet that is deficient in both protein and energy (this occurred in I $\%$ of the households that were studied) is likely to lead to growth retardation at one end of the scale and to nutritional marasmus at the other end of the scale. As a consequence, the nutrition surveys revealed that there was almost universal growth retardation and that there were cases of marasmus among $\mathrm{I}-3 \%$ of the children examined.

The second group, whose diet is not deficient in protein but restricted in energy, is facing a situation in which the quality of the diet, as far as protein is concerned, is good but, owing to restricted consumption of energy, they are not able to utilize the protein in their diet. The NDP: $\mathrm{E}$ ratio of the diet is quite high; clearly, the need here is to provide more energy without regard for protein concentration of the diet. The proportion of such households in this group is $27 \%$ as against I $\%$ of energy-deficient, protein-deficient households ( $25 \%$ for rural areas and $31 \%$ for urban areas). It is clear that the greatest part of the protein deficiency is conditioned by energy intake below the critical limit. Thus, this type of dict will be associated with almost universal growth retardation in children. Early clinical manifestations of protein-energy malnutrition will also be met with frequently: the clinical findings of the West Pakistan Nutrition Survey substantiate this prediction.

The largest group, comprising $60.1 \%$ of the households, may be termed normal. They consume adequate quantities of both protein and energy and, therefore, are expected to be healthy.

Lastly, those households whose diets contain an adequate amount of energy but are deficient in protein are in fact taking an imbalanced diet heavily tilted towards energy. They constitute only a small fraction, $2 \%$, of the households studied. This type of diet has been reported to be associated with both human and experimental kwashiorkor (Platt, Heard \& Stewart, I964; Jelliffe, I968).

If we assume that there is a continuous gradation in protein and energy consumption, as implied in the bivariate distribution, the chances are that only a fraction of these households will have children with frank kwashiorkor. The lowest-income group is most likely to suffer from such a situation owing to wrong weaning practices. The supplementary food for such children will mostly consist of starchy gruels overdiluted with water to reduce the protein concentration sufficiently. Otherwise there is no reason why such a situation should occur at all in Pakistan.

The diet in Pakistan is based mainly on the staples wheat and maize, which are 
usually eaten with some sort of pulses and fresh vegetables. Such a diet can in theory meet the protein needs of all human beings, including infants (Aykroyd \& Doughty, 1964; Miller \& Payne, 1969). Therefore, any cases of kwashiorkor that may occur in this $2 \%$ of households will be due to the ignorance of the mothers about the correct weaning diet for their children. Nutrition education should play an important part in the prevention of malnutrition in this group because the basic foods for providing enough protein are present in the household dict. That is why, perhaps, it was not surprising that in the nutrition survey of West Pakistan no frank cases of kwashiorkor were reported.

Since in infants, the NDP:E ratio equals that of an adult man of the reference type, that is protein concentration in the diet of the reference man and of the infant should be the same, the belief that infants need a concentrated protein mixture is not based on sound scientific facts. However, owing to the special circumstances of the infants, the traditional weaning periods must be taken care of by special preparations suitable for children.

The above discussions have shown clearly the primary need for an improvement in our diet. The main deficiency is one of energy and not of protein. Similar findings have been reported from India (Gopalan, 1968 ; Sukhatme, $1970 b$ ) where the diet is similar to ours. In fact, we have been consuming more than our requirement of protein, even after $10 \%$ for wastage has been subtracted. Even so, protcin deficiency is widespread, because the greater part of the protein deficiency is conditioned by the low-energy content of our diet; so calling for the production of more and more protein from various sources will do little to improve the present situation. Our goal, therefore, should be to increase the amount of total food production, and that in itself will take care of most of our protein problem in Pakistan.

I acknowledge the help of the staff of the Field Sub-division of the Nutrition Division, National Health Laboratories, for making all the calculations in this paper, and the Director of Nutrition and the Executive Director, National Health Laboratories, Islamabad for permission to use the survey records. I am grateful to Dr P. V. Sukhatme, Director, Statistics Division, FAO, for clarifying certain points which arose during the preparation of this paper and for providing useful references from his work.

\section{REFERENCES}

Aykroyd, W. R. \& Doughty, J. (I964). F.A.O. nutr. Stud. no. I9.

Chatfield, C. (I954). F.A.O. nutr. Stud. no. i $\mathrm{I}$

FAO (г957). F.A.O. nutr. Stud. no. 15, p. 16.

FAO (1965). F.A.O. Nutr. Mtg Rep. Ser. no. 37, p. 22.

Gopalan, C. (1968). In Calorie Deficiencies and Protein Deficiencies p. 49 [R. A. McCance and E. M. Widdowson, editors]. London: J. \& A. Churchill.

Government of Pakistan (1970). Nutrition Survey of West Pakistan. A report issued by the Directorate of Nutrition Survey and Research, Ministry of Health, Labour, Social Welfare and Family Planning (Health Division).

Jelliffe, D. B. (1968). Monograph Ser. W.H.O. no. 29.

Miller, D. S. \& Payne, P. R. (I961). F. Nutr. 75, 225.

Miller, D. S. \& Payne, P. R. (I969). Proc. Nutr. Soc. 28, 225. 
National Science Council of Pakistan (1968). Protein Problem of Pakistan. Report of the Protein Committee appointed by the National Science Council, Pakistan.

Platt, B. S., Heard, C. R. C. \& Stewart, J. R. C. (1 964). In Mammalian Protein Metabalism Vol. 2, ch. 21 [H. N. Munro and J. B. Allison, editors]. New York and London: Academic Press.

Sukhatme, P. V. (196r). fl R. statist. Soc. 124, 463 .

Sukhatme, P. V. (1970a). Proc. Nutr. Soc. 29, 176.

Sukhatme, P. V. (1970b). Br. $\mathcal{F}$. Nutr. 24, 477. 